\title{
Repair Complex
}

National Cancer Institute

\section{Source}

National Cancer Institute. Repair Complex. NCI Thesaurus. Code C13723.

Initial or intermediate protein-DNA complexes present during the process of DNA repair. 